\title{
Ostrich Eggs of Predynastic Egypt
}

\section{•د ـ دينا محمد عز الدين توفيق}

Ostriches were hunted by the Egyptians from earliest times. This practice was commemorated on rock- drawings dating to the Predynastic Period.

Ostrich eggs were widely used during that period in order to serve various purposes. Their contents provided food, whereas emptied eggs were used as containers. Small ornaments were also made from ostrich egg-shells which are considered to be amongst the earliest objects of any kind from Ancient Egypt. From the Badarian Period onwards, the shells were worked into jewellery. They were employed for disc beads, pendants and amulets.

On the other hand, a few ostrich eggs were decorated with incised or painted designs which took the form of geometric decoration or drawings of birds and animals. These decorated eggs are of a great interest from an archaeological point of view, they shed light upon an important era of the Ancient Egyptian civilization.

• كلية السياحة و الفنادق-جامعة الاسكندرية - ألقي ملفص البحث ولم يقام البحث للنشر بكتاب 